\title{
A Case Report of Acute Disseminated Encephalomyelitis in a Pregnant Woman After COVID-19 Infection
}

\author{
Gebelikte COVID-19 Enfeksiyonu Sonrası Gelişen Akut Dissemine Ensefalomiyelit \\ Olgu Sunumu
}

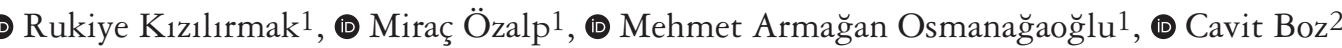 \\ ${ }^{1}$ Karadeniz Technical University Faculty of Medicine, Department of Obstetrics and Gynecology, Clinic of Perinatology, Trabzon, Turkey \\ 2Karadeniz Technical University Faculty of Medicine, Department of Neurology, Trabzon, Turkey
}

\begin{abstract}
A 32-year-old multiparous woman at 29 weeks of gestation developed dizziness, fainting, meaningless and difficult speech, stiffness in the extremities, and movement limitation following the non-severe coronavirus disease-2019 (COVID-19) infection. Magnetic resonance imaging of the brain revealed hyperintense lesions in the white matter on T2-weighted and fluid-attenuated inversion recovery (FLAIR) sequences. The COVID-19 nasopharyngeal swab test in our center resulted negative; however, the serum COVID-19 antibody was positive. The cerebrospinal fluid was clear, no pathogen was reproduced in the culture, and the oligoclonal band was negative. Intravenous pulse steroid therapy and six cycles of plasmapheresis were administered. The symptoms improved partially; however, full recovery could not be achieved despite the treatment. This case emphasizes that acute disseminated encephalomyelitis, which can have severe consequences, should be considered in the differential diagnosis of neurological symptoms in pregnant women who are infected with COVID-19.
\end{abstract}

Keywords: Acute disseminated encephalomyelitis, COVID-19, neuropathology, pregnancy, SARS-CoV-2

$\ddot{O} \mathbf{z}$

Otuz iki yaşında, 29 haftalık hamile bir kadında, şiddetli olmayan koronavirüs hastalığı-2019 (COVID-19) enfeksiyonunun ardından baş dönmesi, bayılma, anlamsız ve zor konuşma, ekstremitelerde sertlik ve hareket kısıtlılığ1 gelişti. Beyin manyetik rezonans görüntülemede beyaz cevherde T2 ağırlıklı ve sıvı sıvı zayıflatılmış inversiyon kurtarma (fluid-attenuated inversion recovery, FLAIR) sekanslarda hiperintens lezyonlar gözlendi. Merkezimizde yapılan COVID-19 nazofaringeal sürüntü testi negatif sonuçlanırken, serum COVID-19 antikor testi pozitif çıktı. Beyin omurilik sıvısı berraktı, kültürde patojen üremedi ve oligoklonal bant negatifti. İntravenöz pulse steroid tedavisi ve altı kür plazmaferez uygulandı. Tedaviye rağmen semptomlar kısmen düzelse de tam iyileşme sağlanamadı. Bu olgu, COVID-19 ile enfekte gebelerde nörolojik semptomların varlığında ciddi sonuçları olabilen akut dissemine ensefalomiyelitin ayırıcı tanıda düşünülmesi gerektiğini vurgulamaktadır.

Anahtar Kelimeler: Akut dissemine ensefalomiyelit, COVID-19, nöropatoloji, gebelik, SARS-CoV-2

\section{Introduction}

Acute disseminated encephalomyelitis (ADEM) is an immunemediated demyelinating disease of the central nervous system (CNS). ADEM is a monophasic disorder that is characterized by multifocal neurological symptoms and encephalopathy that is rare in the adult population. Cases are reported after vaccination or bacterial infection, but the disease mainly occurs after viral infections (1).

Neurological complications that develop based on coronavirus disease-2019 (COVID-19) disease during the current pandemic period are roughly observed in one-third of patients, especially myalgia, headache, and encephalopathy. Neurological symptoms were observed to occur more in severe disease forms and younger patients $(2,3)$. The clinical course of COVID-19 disease remains unclear, and more literature information is needed for its effects on both maternal and fetal morbidity and mortality (4).

This report aimed to share the prenatal and postnatal processes of an ADEM case that developed after COVID-19 infection during pregnancy.

\section{Case Report}

A 32-year-old female patient, G3P2, and at 26 weeks of gestation, contacted. COVID-19 from her infected mother, thus a severe acute respiratory syndrome-coronavirus-2 (SARS-CoV-2)

Address for Correspondence/Yazışma Adresi: Miraç Özalp MD, Karadeniz Technical University Faculty of Medicine, Department of Obstetrics and Gynecology, Clinic of Perinatology, Trabzon, Turkey Phone: +90 5052234093 E-mail: ozalpmirac@gmail.com ORCID: orcid.org/0000-0002-2255-1642 Received/Geliş Tarihi: 17.09.2021 Accepted/Kabul Tarihi: 24.11.2021

${ }^{\circ}$ Copyright 2021 by Turkish Neurological Society Turkish Journal of Neurology published by Galenos Publishing House. 
polymerase chain reaction (PCR) test was performed, which revealed a positive result. The patient who only complained of nausea was hospitalized, and supportive treatment was started. She had not received specific treatment for COVID-19. She was discharged from the hospital 2 days after her symptoms regressed. Ten days after discharge, she was readmitted to the emergency department of the same hospital due to loss of consciousness, decreased communication, inability to sleep, agitation, and spasticity in the right upper and lower extremities. After her first examination, she was admitted to the intensive care unit and started with empirical antibiotherapy (ceftriaxone), antiviral (acyclovir), and antipsychotic (olanzapine) treatment with the diagnosis of meningoencephalitis. As the patient's condition did not improve with the treatment, she was referred to our university hospital from an external center. Written informed consent was obtained from the patient and her family.

The first examination in our emergency department revealed that the patient was conscious, disorientated, non-cooperative, and agitated. Neck stiffness, right upper extremity spasticity, inappropriate extremity movements, and titubation in the head were observed. The patient had a swallowing reflex and could be fed orally. Glasgow Coma score was calculated as 9.

The patient was 29 weeks of pregnancy according to the last menstrual period and did not have the first and second-trimester screening tests. The basic ultrasound examination revealed a single fetus that is consistent with the gestational week without any gross anomaly and with sufficient amniotic fluid. Antenatal dexamethasone administration was performed considering the possible preterm birth risk due to COVID-19 infection and the prognosis of the mother. Daily fetal well-being was evaluated during the period from the hospitalization period to the labor and delivery of the patient. Unless there was an acute deterioration in maternal status, it was planned to maintain the pregnancy until the 34th week.

In the brain magnetic resonance imaging (MRI) of the patient, hyperintense lesions were observed in T2-weighted and fluid-attenuated inversion recovery (FLAIR) sequences, starting from the left frontal subcortical white matter and extending to the deep white matter and the corpus callosum genus (Figure 1). The patient's clinic and examination findings were compatible with postinfectious disseminated leukoencephalopathy (possibly associated with post-COVID infection). Therefore, she was admitted to the neurology inpatient clinic for further research and treatment with a pre-diagnosis of postinfectious disseminated leukoencephalopathy.

A lumbar puncture was performed. Cytological examination of the cerebrospinal fluid (CSF) was determined as benign. The CSF microscopic examination revealed ten leukocytes in the Thoma, without bacteria. The CSF culture revealed no bacterial growth. CSF immunoglobulin G index was 1.96, and the oligoclonal band was found negative. The CSF protein level was $55 \mathrm{mg} / \mathrm{dl}$. Cytomegalovirus (CMV), Epstein-Barr virus, herpes simplex virus (HSV), adenovirus, enterovirus, COVID-19 PCR test was negative in the CSF. Complete blood count, fibrinogen, antinuclear antibody, anti-extractable nuclear antigen, anti-double-stranded DNA, antineutrophil cytoplasmic antibody, antiphospholipid antibody blood tests were performed. Varicella, CMV, HSV, rubella, Syphilis, Borrelia, and Brucella tests on blood were negative. No pathogen was detected in the respiratory panel. Tumor markers
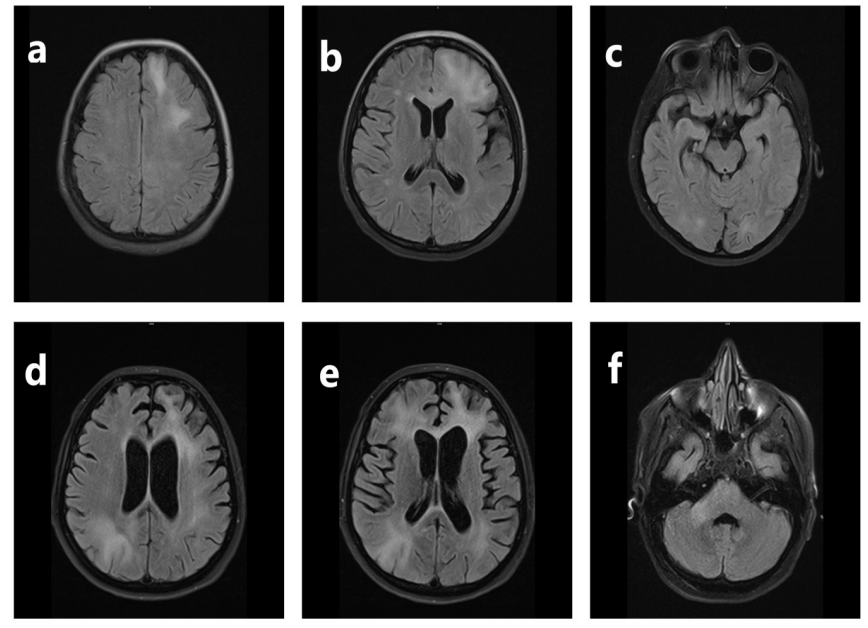

Figure 1. Brain MRI axial FLAIR sequences (a), (b), (c): Patient's first MRI. Hyperintense lesions in the occipital area extend from the left frontal subcortical white matter to the corpus callosum genu. (d), (e), (f): MRI performed after 10 days. Hyperintense lesions on bilateral frontal lobe white matter as more prominent on the left parietal and temporal lobe white matter, anterior corpus callosum, bilateral occipital white matter, and cerebellar peduncle

MRI: Magnetic resonance imaging, FLAIR: Fluid-attenuated inversion recovery

for malignancy screening were negative. No lesion was found in the neck, abdominal, and thoracic computed tomography was suggestive of malignancy. Autoimmune, toxic, and vascular causes were excluded from the laboratory tests for leukoencephalopathy etiology.

Pulse $1000 \mathrm{mg}$ of methylprednisolone treatment was administered to the patient for 5 consecutive days. After the steroid therapy, the patient's agitation decreased, and visual followup began. The patient had no verbal output, and the following of command was partially present. The second course of steroid therapy was applied. Afterward, her inappropriate movements disappeared, and her affection was found to be natural. She began to appropriately react to events. The lesion was enlarged in the brain MRI while receiving the second pulse steroid treatment. It was reported that the choline (Cho)/ $\mathrm{N}$-acetyl aspartate (NAA) ratio significantly increased in MR spectroscopic measurements in the left frontal lobe white matter (Cho: 67 ppm, NAA: 7.8 ppm). When evaluated together with previous MRIs of the patient, they were interpreted as demyelinating lesions.

A total of 6 cycles of plasmapheresis every other day was applied to the patient. No significant improvement was determined with plasmapheresis. During the first dose of plasmapheresis therapy, the treatment was slowed since myoclonus developed in the patient's left arm and leg. Afterward, plasmapheresis was stopped, and electroencephalography (EEG) was obtained, which revealed diffuse slowing and sharp theta wave. Plasmapheresis was continued after EEG. Antiepileptic (levetiracetam) was initiated for the patient. During the plasmapheresis treatment, the patient's left upper and lower extremity myoclonic jerks, usually 4-5 times in a minute continued for 1 hour. These attacks did not occur during sleep. The antiepileptic dose was increased, and valproic acid was added to the treatment. The frequency and severity of 
the patient's seizures decreased. Plasmapheresis was administered together with $1 \mathrm{~g}$ of intravenous pulse steroid for the last 4 days.

At the $34^{\text {th }}$ week of pregnancy, a $2150 \mathrm{~g}$ male baby with $1-5$ minutes APGAR scores of 6-8 was delivered by cesarean section. The SARS-CoV-2 PCR swab test and serum COVID-19 antibody test performed to evaluate vertical transmission to the newborn were negative. The newborn was admitted to the inpatient clinic after being followed up in the neonatal intensive care unit for 3 days due to respiratory distress syndrome and nosocomial sepsis. The baby was discharged from the hospital on the $12^{\text {th }}$ day.

A contrast-enhanced brain MRI was performed after birth. The patient's lesions did not enhance contrast and showed neither regression nor progression. No changes were found in the patient's findings. A brain biopsy was performed 20 days after a plasmapheresis treatment, which was reported as diffuse hypoxia (red neuron) in the neurons in some parenchymal regions, without malignant cells. Cyclophosphamide at $1000 \mathrm{mg} / \mathrm{month}$ was planned to be administered to the patient once a month for 6 months. She was discharged with the recommendation of outpatient control visits.

\section{Discussion}

The association of CNS symptoms with COVID-19 development and the virus that affects the brain has not been fully elucidated. The virus is known to use the angiotensin-converting enzyme 2 (ACE2) receptor to enter the cells. The ACE2 receptor that is expressed on the glial cells and neurons makes CNS a possible target of the virus. The virus is suggested to infect the cerebral tissue by reaching it via the systemic circulation or by axonal transport along with the cribriform plate of the ethmoid bone. SARS-CoV-2 causes a series of changes in viral gene expression in the cell it enters through the ACE2 receptor. Imbalance in neuroinflammation, oxidative stress, thrombotic response, and vasodilation after this change may play a role in the pathophysiology of COVID-19-related CNS symptoms $(5,6,7)$.

ADEM is a sudden-onset encephalopathy that presents with non-specific neurological symptoms and altered consciousness. ADEM cases have been reported after the parainfluenza virus, CMV, Zika virus, and tetanus vaccine in pregnant women $(8,9,10,11)$. The prognosis is generally good in these cases; however, decompressive craniectomy was performed due to severe cerebral edema in an ADEM case that developed after asymptomatic CMV infection. This case shows that the disease can sometimes be life-threatening (11). ADEM is an immune-mediated demyelinating inflammatory disease at the severe end of the neurological spectrum caused by COVID-19. Therefore, diagnosing and initiating prompt treatment is vital. Pregnancy is generally considered protective in active demyelination, but more studies are needed to understand the effect of pregnancy on ADEM development (10). To the best of our knowledge, this is the first case of ADEM in the literature after COVID-19 infection during pregnancy.

The presence of bilateral and asymmetric hyperintens brain lesions in the supratentorial and/or infratentorial white matter on T2-weighted and FLAIR MRI sequences are the distinguishing radiological features of this disease (7). When the neuropathology in the presented case is examined, our case was thought to be ADEM as the clinical findings were postinfectious, with contrast enhancement and deep white matter changes in MRI, and CSF analysis results.
The effect of birth on ADEM regression is unknown. Our patient had no significant improvement or worsening after delivery. Our patient was treated with known treatments for ADEM. A partial improvement was observed in the symptoms; however, no complete recovery was achieved. ADEM is generally a benign disease, but it caused neurologic sequelae in our case.

Future studies will elucidate the neurological effects and longterm consequences of COVID-19 infection. Our knowledge about the clinical spectrum of the disease in the pregnant population is still limited during the current COVID-19 pandemic process, thus collaboration between clinical branches is extremely important for prompt disease diagnosis and treatment to overcome this situation.

\section{Ethics}

Informed Consent: Written informed consent was obtained from the patient and her family.

Peer-review: Internally peer-reviewed.

\section{Authorship Contributions}

Surgical and Medical Practices: R.K., M.Ö., C.B., Concept: M.A.O., C.B., Design: M.A.O., C.B., Data Collection or Processing: R.K., M.Ö., C.B., Analysis or Interpretation: R.K., M.Ö., M.A.O., C.B., Writing: R.K., M.Ö., C.B.

Conflict of Interest: The authors have not declared any conflict of interest related to this article

Financial Disclosure: No financial support was received from any institution or person for our study.

\section{References}

1. Pohl D, Alper G, Van Haren K, et al. Acute disseminated encephalomyelitis: Updates on an inflammatory CNS syndrome. Neurology 2016;87:S38-S45.

2. Romero-Sánchez CM, Díaz-Maroto I, Fernández-Díaz E, et al. Neurologic manifestations in hospitalized patients with COVID-19: The ALBACOVID registry. Neurology 2020;95:e1060-e1070.

3. Liotta EM, Batra A, Clark JR, et al. Frequent neurologic manifestations and encephalopathy-associated morbidity in Covid-19 patients. Ann Clin Transl Neurol 2020;7:2221-2230.

4. Ozalp M, Demir O, Akbas H, et al. Effect of COVID-19 pandemic process on prenatal diagnostic procedures. J Matern Fetal Neonatal Med 2021;34:39523957

5. Divani AA, Andalib S, Biller J, et al. Correction to: Central Nervous System Manifestations Associated with COVID-19. Curr Neurol Neurosci Rep 2020;20:66.

6. Baig AM, Khaleeq A, Ali U, Syeda H. Evidence of the COVID-19 Virus Targeting the CNS: Tissue Distribution, Host-Virus Interaction, and Proposed Neurotropic Mechanisms. ACS Chem Neurosci 2020;11:995-998.

7. Langley L, Zeicu C, Whitton L, Pauls M. Acute disseminated encephalomyelitis (ADEM) associated with COVID-19. BMJ Case Rep 2020;13:e239597.

8. Zeb Q, Alegria A. Acute disseminated encephalomyelitis (ADEM) following a $\mathrm{H} 3 \mathrm{~N} 3$ parainfluenza virus infection in a pregnant asthmatic woman with respiratory failure. BMJ Case Rep 2014;2014:bcr2013201072.

9. Cisse FA, Sidibe H, Morel Y, Ndiaye M, Diop AG, Ndiaye MM. Encéphalomyélite aiguë disséminée après vaccination antitétanique : une observation chez une femme enceinte au Sénégal [Acute disseminated encephalomyelitis after tetanus vaccination of a pregnant woman in Senegal]. Med Sante Trop 2012;22:103-105.

10. Carod-Artal FJ. Neurological complications of Zika virus infection. Expert Rev Anti Infect Ther 2018;16:399-410.

11. Macerollo A, Dalfino L, Brienza N, et al. Life-threatening ADEM in an immunocompetent pregnant woman with concomitant asymptomatic Cytomegalovirus infection. J Neurol Sci 2016;364:53-55. 